\title{
Pengaruh Pemberian Ekstrak Daun Sirih Merah (Piper crocatum) Terhadap Kadar LDL Darah Mencit
}

\author{
Surya Dharma1, , ${ }^{*}$ Fitrini2, Zulkarni \\ 1. Bagian Farmakologi \& Farmasi Klinis Fakultas Farmasi Universitas Andalas, Padang \\ 2. Bagian Farmakologi STIFI Perintis, Padang \\ *Email korespondensi: suryadharma1954@yahoo.com
}

(Submit 15/03/2019, Revisi 05/09/2019, Diterima 20/12/2019)

\begin{abstract}
Abstrak
Daun sirih merah (Piper crocatum) mengandung senyawa yang salah satunya flavonoid, dimana besar peranannya sebagai anti oksidan dalam pembuluh darah di jantung dan otak. Antioksidan diasumsikan dapat menghambat peradangan yang disebabkan oleh tingginya kadar LDL dalam pembuluh darah. LDL merupakan lemak jenuh yang bersifat radikal bebas yang dapat menimbulkan peradangan pada pembuluh darah. Penelitian ini dilakukan bertujuan agar kandungan senyawa flavonoid ini mampu mengantisipasi pembentukan radang di dalam pembuluh darah, sehingga aterosklerosis dan trombosis dapat dicegah. Metode yang digunakan adalah dengan optimalisasi kadar LDL dalam darah dengan cara pemberian kuning telur puyuh. Hewan uji terdiri atas 5 kelompok setiap kelompok terdiri dari 6 ekor mencit. Kelompok 1 merupakan kelompok yang hanya diberikan makanan standar, CMC dan air. Kelompok 2 adalah kelompok yang diberikan kuning telur selama 14 hari. Kelompok 3,4 dan 5 diberikan variasi dosis ekstrak sirih merah secara berurutan (200, 280 dan $400 \mathrm{mg} / \mathrm{kg} \mathrm{BB}$ ). Penelitian dilakukan selama 21 hari, diamati pada hari ke 7, 14 dan 21. Kadar LDL diukur menggunakan alat Lipid Pro. Setelah dihitung diperoleh data bahwa pemberian dosis $400 \mathrm{mg} / \mathrm{kg}$ BB pada pengamatan hari ke 14 dan 21, merupakan dosis yang mampu menurunkan kadar LDL darah secara maksimal $(p<0,05)$ baik berdasarkan hasil data yang diperoleh maupun dihitung dalam bentuk persentase. Efek dalam bentuk persentase, dibandingkan dengan kontrol positif disetiap waktu pengamatan yang sama. Pemberian ekstrak daun sirih merah dosis $400 \mathrm{mg} / \mathrm{kgBB}$ pada hari ke 14 dan 21, mampu menurunkan kadar LDL dengan maksimal $(p<0.05)$ pada mencit putih sebagai hewan uji.
\end{abstract}

Kata kunci: sirih merah, LDL

\section{Outline}

- Pendahuluan

- Metode

- Hasil dan Pembahasan

- Kesimpulan

- Ucapan Terima Kasih

- Daftar Pustaka 


\section{Pendahuluan}

Menurut data WHO pada tahun 2011, sebesar 35,1\% penduduk Indonesia mengalami peningkatan kadar kolesterol darah. Penelitian yang dilakukan pada tiga kota besar di Indonesia (Jakarta, Bandung, Yogyakarta). Tahun 2004 menunjukkan keadaan dislipidemia berat pada masyarakat yang berusia rata-rata 55 tahun dengan jumlah $56 \%$ di kota Jakarta, 52,2 \% di Bandung, dan 27,7 \% di Yogyakarta ${ }^{1}$.

LDL merupakan lipoprotein berdensitas rendah yang berfungsi mengangkut lemak ke jaringan. Peningkatan LDL kolesterol dalam jangka waktu lama dapat menyebabkan terjadinya penimbunan lemak di dalam lapisan pembuluh darah atau plak kolesterol. Plak kolesterol mengakibatkan terjadinya pengerasan dan penyempitan pembuluh darah sehingga suplai darah ke otot jantung berkurang yang kemudian menyebabkan penyakit jantung. Peningkatan kolesterol antara lain disebabkan oleh faktor genetik, usia, jenis kelamin, aktivitas fisik, penyakit penyerta, kebiasaan merokok, kebiasaan minum kopi, dan pengaturan pola makan. Pengaturan pola makan menurut Krummel (2012) dengan mengurangi asupan makanan dan minuman yang mengandung lemak dapat membantu untuk mengontrol dislipidemia.

Pemanfaatan obat tradisional atau jamu di Indonesia pada hakekatnya merupakan bagian kebudayaan bangsa Indonesia. Keuntungan dari penggunaan obat (ramuan) tradisional pada prinsipnya adalah efek samping yang relativ kecil dibandingkan obat modern. Meskipun secara empiris obat tradisional mampu menyembuhkan berbagai macam penyakit, tetapi khasiat dan kemampuannya belum banyak dibuktikan secara ilmiah maupun klinis. Belum banyak diketahui senyawa kimia apa yang bertanggung jawab terhadap khasiat obat tradisional tersebut ${ }^{2}$.

Salah satu tanaman indonesia yang banyak digunakan untuk pengobatan tradisional adalah sirih merah (Piper crocatum Ruiz \& Pav.). Tanaman sirih merah (Piper crocatum Ruiz \& Pav.) termasuk famili piperaceae ${ }^{3}$. Di dalam P. crocatum Ruiz \&Pav. terkandung bahan-bahan kimia dengan khasiat tertentu yang disebut metabolit sekunder. Senyawa metabolit sekunder yang terdapat dalam daun Piper crocatum Ruiz \&Pav. yaitu alkaloid, saponin, tannin dan flavonoid. Kandungan kimia lainnya yang terdapat di daun Piper crocatum Ruiz \&Pav. antara lain minyak atsiri ${ }^{4}$. Daun sirih merah (Piper crocatum Ruiz \& Pav.) memiliki khasiat, dalam bentuk teh herbal (teh herbal "sirih merah" produksi toeniel; teh herbal "sirih merah"PJ. sekarkedhaton) bisa mengobati asam urat, kencing manis, maag dan kelelahan. Daun sirih merah ini juga digunakan sebagai obat luar dapat memperhalus kulit. Penggunaan Piper crocatum Ruiz \&Pav. dapat digunakan dalam bentuk segar, simplisia maupun kapsul ekstrak (kapsul herbal "sirih merah")4.

Rangkuti et al. (2018) telah melakukan penelitian uji efektivitas nanopartikel daun sirih merah (Piper crocatum Ruiz \&Pav.) sebagai penurun kadar kolesterol serum darah marmot, dimana hasilnya ukuran nanopartikel daun sirih merah yang dihasilkan adalah $900 \mathrm{~nm}$, dengan pemberian dosis $100 \mathrm{mg} / \mathrm{KgBB}$ dan 200mg/KgBB dapat memberikan efek penurunan kadar kolesterol yang tidak berbeda dengan pemberian suspensi simvastatin dapat di amati pada hari ke -21 , penurunan kolesterol berada di bawah 43 $\mathrm{mg} / \mathrm{dl}$ atau batas normal ${ }^{5}$. Yulinta et al. (2013), telah melakukan penelitian efek 
toksisitas ekstrak daun sirih merah terhadap gambaran mikroskopis ginjal tikus putih diabetik yang di induksi aloksan, dimana hasil dari pemberian ekstrak etanol daun sirih merah pada dosis $50 \mathrm{mg} / \mathrm{KgBB}$ dan $100 \mathrm{mg} / \mathrm{KgBB}$ tidak toksik terhadap gambaran mikroskopik ginjal tikus putih diabetes militus yang diinduksi aloksan ${ }^{6}$. Oleh sebab itu, berdasarkan uraian di atas peneliti mencoba melakukan penelitian tentang efek pemberian ekstrak metanol daun sirih merah terhadap kadar LDL (Low Density Lipoprotein) pada mencit putih jantan.

\section{Metode}

\section{A. Alat dan Bahan}

Alat yang digunakan adalah Botol reagen gelap, rotary evaporator $\left(\mathrm{Ika}^{\circledR}\right)$, timbangan analitik (OHAUS ${ }^{\circledR}$ ), timbangan hewan, kandang hewan, tabung reaksi (Pirex ${ }^{\circledR}$ Iwaki) dan rak tabung reaksi, corong (Pyrex ${ }^{\circledR}$ ) pipet tetes, gelas ukur (Pirex ${ }^{\circledR}$ Iwaki), alumunium foil $\left(\right.$ Klinpak $\left.^{\circledR}\right)$, jarum oral, penangas air, erlemeyer $\left(\right.$ Pyrex $\left.^{\circledR}\right)$, kaca arloji, oven, cawan porselen. Krus porselen, batang pengaduk ,cawan penguap, lumpang, stamfer, kertas tisu, kapas, spatel, sudip, sonde, beaker glass, pinset, Lipid Pro ${ }^{\circledR}$.

Bahan yang digunakan adalah daun sirih merah, Metanol (PT. Brataco), kuning telur punyuh, Natriumcarboxy methyl cellulose (Na-CMC) (PT. Brataco), Etanol $70 \%$, Mayer $\left(\mathrm{KHgl}_{4}\right)$, serbuk $\mathrm{Mg}, \mathrm{H}_{2} \mathrm{SO}_{4}, \mathrm{HCl}, \mathrm{FeCl}_{3}$, asetatanhidrat, kloroform amoniak, tes strip untuk kadar LDL, aquadest dan makanan standar mencit.

\section{B. Prosedur Penelitian}

\section{Pengambilan sampel}

Sampel yang digunakan pada penelitian ini adalah daun sirih merah (Piper crocatum) Daun segar yang diambil di daerah Lubuk Minturun Kota Padang, Sumatera Barat.

\section{Pembuatan ekstrak daun sirih merah}

Sampel yang diambil dari tanaman Piper crocatum Ruiz \& Pav. adalah daunnya. Daun segar bersihkan dan rajang, selanjutnya letakkan di dalam wadah dan timbang. Sampel yang telah ditimbang $1 \mathrm{~kg}$ dan telah dirajang dimasukkan dalam botol maserasi dan ditambahkan metanol sampai terendam. Dibiarkan di tempat gelap selama 3 hari sambil sekali-sekali diaduk. Dipisahkan hasil maserasi dengan penyaringan menggunakan kapas. Diulangi maserasi sampai 3 kali sehingga diperoleh hasil maserasi yang agak bening. Gabungan ekstrak metanol diuapkan dengan rotary evaporator sehingga diperoleh ekstrak kental.

\section{Karakterisasi sampel}

Karakterisasi sampel yang dilakukan adalah randemen, pemeriksaan organoleptis, penentuan susut pengeringan dan uji fitokimia ${ }^{7,8}$.

\section{Persiapan hewan uji}

Hewan uji yang digunakan adalah mencit putih jantan yang sehat dengan berat badan 20-30 g, berumur 2-3 bulan, sebanyak 30 ekor. Mencit diaklimatisasi selama 7 hari. 
Hewan dinyatakan sehat apabila penyimpangan berat badan sebelum dan sesudah diadaptasikan tidak lebih dari $10 \%$ dan secara visual menunjukkan prilaku normal.

\section{Pembuatan induksi}

Induksi yang digunakan untuk membuat mencit hiperkolesterol adalah kuning telur puyuh. Di pisahkan kuning dengan putihnya, diambil 20 gram lalu dikocok hingga homogen.

\section{Dosis uji}

Dosis sediaan ekstrak metanol daun sirih merah diberikan pada hewan uji adalah 200; $280 \mathrm{mg}$ dan $400 \mathrm{mg} / \mathrm{kg}$ BB yang diberikan secara oral.

\section{Perlakuan hewan percobaan}

Hewan percobaan diaklimatisasikan selama satu minggu, selanjutnya hewan uji dibagi menjadi 5 kelompok yaitu :

Kelompok 1 : Kelompok kontrol negatif, diberikan makanan standar dan Na CMC

Kelompok 2 : Kelompok kontrol positif, diberikan kuning telur selama 2 minggu dan $\mathrm{Na}$ $\mathrm{CMC}$.

Kelompok 3 : Kelompok perlakuan, diberikan induksi kuning telur selama 2 minggu, dosis daun sirih merah $200 \mathrm{mg} / \mathrm{kgBB}$ dan CMC selama 21 hari.

Kelompok 4 :Kelompok perlakuan, diberikan induksi kuning telur selama 2 minggu, dosis daun sirih merah $280 \mathrm{mg} / \mathrm{kgBB}$ dan CMC selama 21 hari

Kelompok 5 :Kelompok perlakuan, diberikan induksi kuning telur selama 2 minggu, dosis daun sirih merah $400 \mathrm{mg} / \mathrm{kgBB}$ dan CMC selama 21 hari

\section{Tahap pengujian}

Diaklimatisasi kelompok hewan uji selama 7 hari, lalu mencit di kelompokkan dalam 5 kelompok dalam 1 kelompok terdiri dari 6 hewan percobaan, kelompok 1 diberi suspensi $\mathrm{Na}$ CMC $0,5 \%$ secara peroral, kelompok II, III, IV, dan V diberi penginduksi menggunakan kuning telur puyuh secara peroral selama 2 minggu. Setelah kadar LDL optimal, kelompok III, IV dan V diberi ekstrak daun sirih merah dengan dosis berturutturut $200 ; 280$; dan 400 mg/kgBB selama 21 hari dan diamati pada hari ke $7 ; 14$ dan 21.

\section{Pengukuran kadar LDL}

Pengukuran dilakukan dengan alat digital Lipid Pro®. Alat dikalibrasi dahulu dengan nomor kode yang disesuaikan dengan tes strip yang akan digunakan. Tes strip diselipkan pada tempat khusus pada alat, kemudian pada layar akan muncul gambar untuk stel waktu, tanggal, hari, jamdan satuan kadar LDL nya, tetesan darah yang menandakan alat siap digunakan. Darah mencit diambil melalui vena ekor (vena coccygeal).Ekor mencit didisinfektan dengan etanol $70 \%$ kemudian baru ditusuk, tetesan darah pertama dibuang tetesan berikutnya diserapkan pada strip kadar LDL sampai terdengar bunyi, setelah itu pendarahan pada ekor mencit dihentikan. Dalam beberapa detik pada layar akan tertera kadar LDL dalam $\mathrm{mg} / \mathrm{dL}$. Uji dilakukan pada setiap mencit pada semua kelompok. 
10. Analisa Data

Data dari hasil penelitian ini akan dianalisis secara statistik dengan menggunakan analisis varian (ANOVA) dua arah dan dilanjutkan dengan uji wilayah berganda Duncan (Duncan's Multiple Range T-test)

\section{Hasil Dan Pembahasan}

Pada penelitian ini digunakan sampel daun sirih merah (Piper crocatum Ruiz \& Pav.), sampel segar daun sirih merah diambil di daerah Lubuk Minturun Kota Padang, Sumatera Barat. Identifikasi tumbuhan daun sirih merah telah dilakukan di Herbarium Universitas Andalas (ANDA) Laboratorium Jurusan Biologi FMIPA Universitas Andalas Kampus Limau Manih Padang Sumatra Barat. Tujuan identifikasi adalah untuk mengetahui identitas sampel yang akan digunakan. Berdasarkan hasil identifikasi tersebut dapat diketahui kepastian bahwa sampel yang digunakan dalam penelitian ini adalah Piper crocatum Ruiz \& Pav. dengan famili piperaceae.

Daun sirih merah (Piper crocatum Ruiz \& Pav) yang digunakan sebanyak $1 \mathrm{~kg}$ menggunakan metode maserasi. Sampel yang diperoleh dibersihkan dari kotoran dengan cara dicuci dengan air mengalir, kemudian dirajang kecil-kecil, lalu dikering anginkan. Pelarut yang digunakan adalah pelarut metanol dalam suhu kamar terlindung dari cahaya.

Proses maserasi ini dilakukan selama 3 hari perendaman dengan 3 kali pengulangan, dimana selama perendaman sampel sesekali diaduk untuk mempercepat penetrasi pelarut ke dalam sampel sehingga komponen-komponen kimia di dalamnya akan terlarut. Maserat hasil maserasi yang telah disaring dipekatkan dengan rotary evaporator pada suhu $40^{\circ} \mathrm{C}$ sehingga didapatkan ekstrak kental metanol yang tidak dapat dituang ${ }^{7}$. Tujuan dari evaporasi yaitu untuk menguapkan pelarut yaitu metanol, sehingga yang tersisa hanya senyawa aktif atau ekstrak kental metanol. Ekstrak kental metanol yang dihasilkan dari proses maserasi yaitu 102,88 gram dengan rendemen $10,28 \%$.

Selanjutnya dilakukan pemeriksaan karakterisasi terhadap ekstrak daun sirih merah yang meliputi penentuan organoleptik, susut pengeringan, kadar abu dan uji skrining fitokimia. Ekstrak daun sirih merah yang didapatkan berwarna hijau pekat, pahit, baunya khas/ menyengat dan bentuknya kental. Penentuan organoleptik ini termasuk salah satu parameter spesifik yang ditentukan dengan panca indera dan bertujuan untuk pengenalan awal secara sederhana. Setelah itu dilakukan uji susut pengeringan, Tujuan dari penentuan susut pengeringan adalah memberikan batasan maksimal (rentang) tentang besarnya senyawa yang hilang pada proses pengeringan, tidak hanya air tapi senyawa menguap lainnya ${ }^{7}$. Pada penentuan susut pengeringan ekstrak daun sirih merah didapatkan persentase rata-rata adalah 12,9\%. Selanjutnya dilakukan pengujian kadar abu, tujuan penentuan kadar abu untuk mengetahui kandungan mineral dalam sampel, mineral sebagai senyawa anorganik dalam bahan akan tertinggal dalam bentuk $\mathrm{abu}^{7}$. Pada penentuan kadar abu ekstrak daun sirih merah yang telah dilakukan, didapatkan hasil yaitu $6,92 \%$. 
Pada pemeriksaan skrining fitokimia ekstrak metanol daun sirih merah, diperoleh hasil bahwa ekstrak metanol daun sirih merah mengandung flavonoid, steroid, saponin, fenolik dan alkaloid sedangkan terpenoid tidak ditemukan.

Hewan percobaan diaklimatisasi selama 1 minggu sebelum di lakukan penelitian dengan tujuan untuk menyesuaikan diri terhadap lingkungan. Hewan percobaan di kelompokkan menjadi 5 kelompok, tiap kelompok terdiri dari 6 ekor mencit. Dimana kelompok 1 adalah kelompok kontrol negatif yang diberikan Na CMC 0,5\%, kelompok 2 adalah kontrol positif yang diberikan penginduksi dan kelompok 3,4,5 adalah kelompok yang diberi ekstrak metanol daun sirih merah pemberian sedian uji dengan 3 variasi dosis yaitu dosis I (200 mg/kgBB) pada kelompok 3, dosis II (280 mg / kgBB) pada kelompok 4 dan dosis III $(400 \mathrm{mg} / \mathrm{kgBB})$ pada kelompok 5 . Pada pengujian ini yang digunakan sebagai penginduksi kadar LDL pada mencit putih jantan adalah kuning telur puyuh yang diberikan selama 2 minggu. Alat yang digunakan untuk mengukur kadar LDL darah mencit pada penelitian ini adalah digital Lipidpro. Keuntungan alat ini adalah lebih praktis dan waktu pengukurannya relatif. Selain itu, sampel darah yang digunakan sangat sedikit karena dengan metoda lain darah yang dibutuhkan banyak dan ini sulit terpenuhi dengan menggunakan mencit. Prinsip pengukuran kadar LDL dengan alat digital ini adalah metoda enzimatik dimana pada bagian strip dilengkapi dengan "kit pereaksi" yang mengandung enzim, darah mencit akan diserapkan pada bagian ujung strip yang mengandung enzim tersebut. Sebelum darah diambil, ujung ekor mencit dibersihkan terlebih dahulu dengan etanol $70 \%$ yang bertujuan untuk menghindari terjadinnya infeksi. Pengambilan darah menggunakan lanset, tetesan pertamannya dibuang untuk menghindari adanya zat yang akan mengganggu pengukuran. Lalu, tetesan selanjutnya sebanyak 1-2 tetes ditetesin pada kit pereaksi lalu diukur kadar LDL pada mencit.

Dari data statistik dapat diketahui bahwa kadar LDL dari kelompok kontrol positif tinggi dari kadar normal, hal ini menunjukan bahwa induksi kuning telur puyuh pada mencit dapat meningkatkan kadar LDL darah mencit putih jantan. Sedangkan pada kelompok kontrol negatif yang merupakan acuan kadar LDL normal menunjukan bahwa kadar LDLnya stabil pada rentang kadar normal. Pada penelitian ini dapat dilihat bahwa masing-masing dosis memiliki data yang sedikit bervariasi. Perbedaan yang timbul merupakan suatu kewajaran karena perbedaan kondisi fisiologis seperti berat badan, usia, enzim yang dimiliki dan proses metabolisme tubuh dari masing-masing hewan percobaan selama perlakuan yang akan mempengaruhi kadar LDL yang diukur.

Setelah diukur kadar LDL mencit putih jantan yang diberi penginduksi kuning telur selama 2 minggu, kemudian dilanjutkan dengan pemberian ekstrak metanol daun sirih merah selama 21 hari. Pengukuran kadar LDL darah dilakukan pada hari ke-7, 14 dan hari ke-21.

Pensuspensi yang di gunakan untuk mensuspensikan sedian uji adalah Na.CMC 0,5\% karena bersifat stabil, mempunyai tingkat kejernihan yang tinggi, mudah di dapat dan tidak mudah di tumbuhi mikroorganisme. Sediaan uji diberikan secara peroral karena pemberian obat peroral umumnya di gunakan dalam penelitian menggunakan hewan percobaan, disamping itu cara ini lebih aman dan mudah pengerjaanya. 
Tabel 1. Kadar rata-rata LDL dalam darah terhadap perlakuan ekstrak metanol daun sirih merah (Piper crocatum) dengan variasi dosis 200; 280; dan $400 \mathrm{mg} / \mathrm{Kg}$ BB pada pengamatan hari ke 7,14 , dan $21(n=6)$

\begin{tabular}{|c|r|r|r|}
\hline \multirow{2}{*}{ Kelompok } & \multicolumn{3}{|c|}{ Hari ke $(\mathrm{mg} / \mathrm{dll})$} \\
\hline Kontrol negatif & \multicolumn{1}{|c|}{ Ke- 7 } & \multicolumn{1}{|c|}{ Ke -14 } & \multicolumn{1}{|c|}{ Ke-21 } \\
\hline Kontrol positif & $80,33 \pm 1,86$ & $81,00 \pm 2,36$ & $86,00 \pm 3,16$ \\
\hline Dosis 200 mg/KgBB & $226,33 \pm 12,34$ & $225,33 \pm 11,96$ & $209,83 \pm 8,68$ \\
\hline Dosis 280 mg/KgBB & $211,33 \pm 9,62$ & $189,17 \pm 10,68$ & $187,50 \pm 8,52$ \\
\hline Dosis 400 mg/KgBB & $203,83 \pm 9,19$ & $93,33 \pm 3,93$ & $81,67 \pm 2,87$ \\
\hline
\end{tabular}

Kelompok kontrol negatif, merupakan kelompok mencit yang dijadikan sebagai acuan pada penelitian ini karena hanya diberikan $\mathrm{Na}$ CMC 0,5\% atau disebut juga sebagai kelompok normal. Pada hari ke 7, 14 dan 21 diperoleh hasil kadar rata-rata LDL darah mencit dan simpangan bakunya dapat dilihat pada Tabel 1.

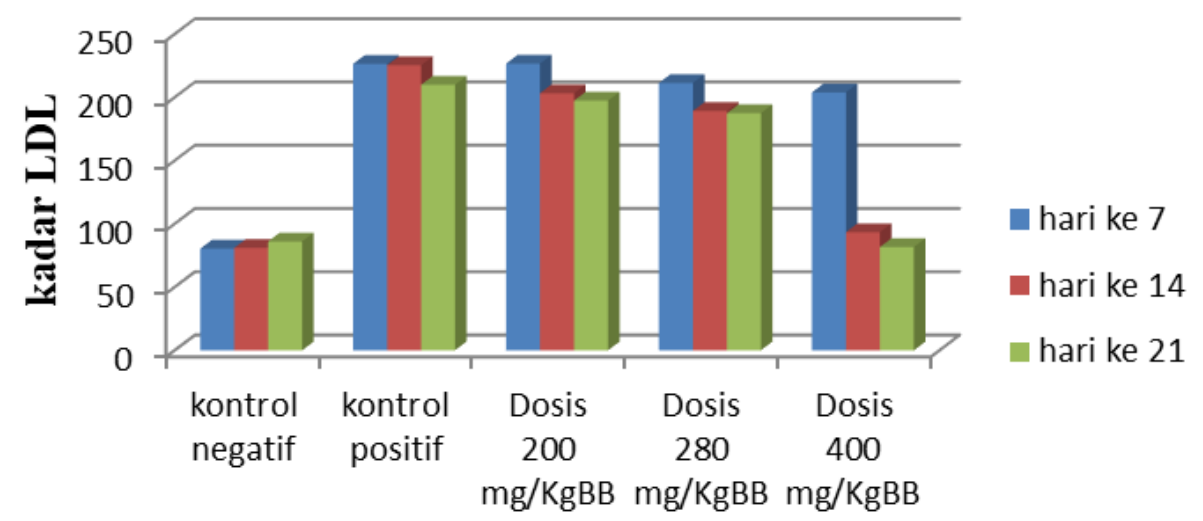

\section{kelompok}

Gambar 1. Diagram batang rata-rata LDL dalam darah terhadap perlakuan ekstrak metanol daun sirih merah (Piper crocatum) dengan variasi dosis 200; 280; dan $400 \mathrm{mg} / \mathrm{Kg}$ BB pada pengamatan hari ke 7, 14, dan 21

Dari hasil rata-rata pengamatan variasi dosis dapat dilihat persentase penurunan kadar LDL dalam darah mencit pada hari pengamatan ke 7, 14, dan 21. Dapat dilihat pada Tabel 2.

Tabel 2. Efek dari tanaman daun sirih merah (Piper crocatum) dalam bentuk persentase pada pengamatan hari ke 7,14 dan 21

\begin{tabular}{|c|c|c|c|}
\hline \multirow{2}{*}{ Kelompok } & \multicolumn{3}{|c|}{$(\%)$ Rata -rata penurunan kadar LDL pada hari ke- } \\
\hline Dosis $200 \mathrm{mg} / \mathrm{KgBB}$ & 7 & 14 & 21 \\
\hline Dosis $\mathbf{2 8 0} \mathrm{mg} / \mathrm{KgBB}$ & $0,017 \%$ & $9,83 \%$ & $5,95 \%$ \\
\hline Dosis $\mathbf{4 0 0} \mathrm{mg} / \mathrm{KgBB}$ & $9,62 \%$ & $16,04 \%$ & $10,64 \%$ \\
\hline
\end{tabular}


Diagram persentase penurunan kadar LDL

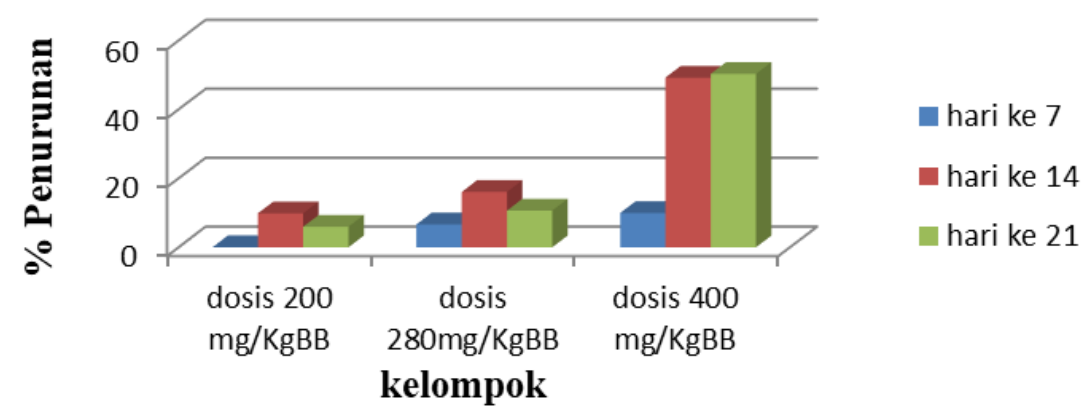

Gambar 2. Diagram batang efek dari tanaman daun sirih merah (Piper crocatum) dalam bentuk persentase pada pengamatan hari ke 7, 14 dan 21.

Dimana dari diagram batang efek dari tanaman daun sirih merah dalam bentuk persentase pada pengamatan 7, 14 dan 21 dan pada dosis $200 \mathrm{mg} / \mathrm{KgBB}, 280$ $\mathrm{mg} / \mathrm{KgBB}$ dan $400 \mathrm{mg} / \mathrm{KgBB}$ dapat dilihat hasilnya ternyata dosis $400 \mathrm{mg} / \mathrm{KgBB}$ yang bagus penurunannya pada pengamatan ke 21 yaitu dengan persentase 50,30\%. Analisa data dengan uji statistik ANOVA dua arah $(p<0,05)$ dilanjut dengan uji Duncan (SPSS 23.0) terhadap kenaikan kadar LDL darah mencit putih jantan didapatkan hasil bahwa kelompok uji 1, uji 2, uji 3 dan kontrol positif berbeda nyata dengan kontrol negatif. kelompok uji 1 tidak berbeda nyata dengan kelompok uji 2, sedangkan kelompok uji 1 tidak berbeda nyata dengan kontrol positif.Pembanding tidak berbeda nyata dengan kontrol negatif akan tetapi berbeda nyata dengan kelompok uji 1 dan kelompok kontrol positif. Sedangkan Data untuk hasil lama pemberian didapatkan hasil bahwa hari ke 7 berbeda nyata dengan hari ke 14 dan 21, sedangkan hari ke 14 tidak berbeda nyata dengan hari ke 21 . Hasil pengujian statistik anova dua arah terhadap kadar LDL darah mencit menunjukkan bahwa ekstrak metanol daun sirih merah mempunyai pengaruh terhadap kadar LDL darah mencit yang ditandai dengan nilai signifikan $p<0,05 y$ ang berarti ada perbedaan secara bermakna antara kelompok yang diberikan sediaan uji, pembanding dengan kelompok kontrol.

\section{Kesimpulan}

Berdasarkan hasil penelitian pengaruh ekstrak methanol daun sirih merah (Piper crocatum Ruiz \&Pav) terhadap kadar LDL (Low Density Lipoprotein) darah mencit putih jantan maka diperoleh kesimpulan yaitu :

1. Pemberiaan ekstrak metanol daun sirih merah (Piper crocatum) pada dosis 400 $\mathrm{mg} / \mathrm{KgBB}$ pada pengamatan hari ke-14 dan 21 terjadi penurunan kadar LDL (Low Density Lipoprotein) yang signifikan $(p<0,05)$ tetapi tidak sama halnya dengan dosis $200 \mathrm{mg} / \mathrm{KgBB}$ dan $280 \mathrm{mg} / \mathrm{KgBB}$.

2. Pemberian ekstrak metanol dosis $200 \mathrm{mg} / \mathrm{kg}$ BB pada pengamatan hari ke 21 , terlihat peningkatan kadar LDL yang signifikan pada $p<0,05$

\section{Ucapan Terima Kasih}

Ucapan terima kasih kami sampaikan kepada Bapak Rektor, Ibu Dekan Fakultas Farmasi Unand, Ketua STIFI Yayasan Perintis Padang serta saudara Fitrini yang telah 
banyak membantu dari segi waktu dan biaya sehingga selesainya penelitian ini dikerjakan.

\section{Daftar Pustaka}

1. World Health Organization. The World Medicine Situation 2011 3ed. Relational Use of Medicine.Geneva.2011.

2. Wijayakusuma, H.M. 1992. Tanaman Berkhasiat Obat Di Indonesia. Jilid 2.Jakarta : Pustaka Kartini.

3. Haviva, A. B. 2011. Sirih Merah Itu Obat Dahsyat. Yogyakarta :Laksana

4. Manoi, F. 2007. Sirih Merah Sebagai Tanaman Multi Fungsi. Warta Puslitbangbun Vol 13 No.2 http://balitro.litbang.deptan.go.id diakses tanggal 19 mei 2018

5. Rangkuti, Saru Noliqo.,Lubis, Lely Sari, Karsono. 2018. Uji Efektivitas Nanopartikel Daun Sirih Merah (Piper crocatum Riz \& Pav.) Sebagai Penurun Kadar Kolesterol Serum Darah Marmot (Cavia cobaya). Farmagazine.Vol. V No. 1.

6. Yulinta, Ni Made Rina.,Gelgel, Ketut Tono Pasek., Kardena, I Made. 2013.Efek Toksisitas Ekstrak Daun Sirih Merah Terhadap Gambaran Mikroskopis Ginjal Tikus Putih Diabetik Yang Diinduksi Aloksan. Buletin Veteriner Udayana. ISSN 2085-2495. Vol. 5. No. 2.

7. Depkes RI. 2008. Farmakope Herbal Indonsia. Edisi 1. Jakarta : Departemen Kesehatan RI.

8. Harborne, J. B. 1978. Metode Fitokimia Dasar penentuan cara modern menganalisa Tumbuhan. Hal 46-47.Bandung : ITB 